\title{
Comparison of HPV genotyping by type-specific PCR and sequencing
}

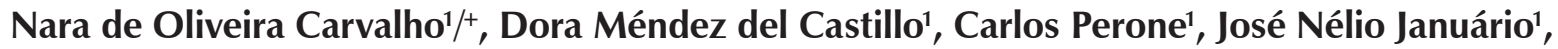 \\ Victor Hugo de Melo², Geraldo Brasileiro Filho ${ }^{3}$
}

\begin{abstract}
${ }^{1}$ Núcleo de Ações e Pesquisas em Apoio Diagnóstico ${ }^{2}$ Centro de Treinamento e Referência em Doenças Infecciosas e Parasitárias Orestes Diniz ${ }^{3}$ Departamento de Anatomia Patológica e Medicina Legal, Faculdade de Medicina, Universidade Federal de Minas Gerais, Belo Horizonte, MG, Brasil
\end{abstract}

Human papillomavirus (HPV) infection is the most common sexually transmitted disease worldwide and there is a strong link between certain high-risk viral types and cervical carcinogenesis. Although there are several typing methods, it is still unclear which test is the best. This study compared the effectiveness of type-specific PCR (TS$P C R)$ and sequencing, with a focus on their clinical application. A total of 260 cervical samples from HPV-positive patients were tested for types $6,11,16,18,31,33$ and 35 using TS-PCR and sequencing. The genotype was identified in $36 \%$ of cases by TS-PCR and in 75\% by sequencing. Sequencing was four times more likely to identify the viral type in positive samples than TS-PCR $(p=0.00)$. Despite being more effective for virus genotyping, sequencing was unable to identify viral types in multiple infections. Combining both techniques resulted in highly sensitive detection (87\% of cases), showing that they are complementary methods. HPV genotyping is an important step in HPV management, helping to identify patients with a higher risk of developing cervical cancer and contributing to the development of type-specific vaccines.

Key words: HPV - PCR - sequencing - typing

Human papillomavirus (HPV) is the most common sexually transmitted virus in young and sexually active people of both sexes (Sanjose et al. 2007). Anogenital HPVs, which are primarily mucosotropic, are classified as high and low risk, according to their relationship with benign or malignant proliferative lesions (de Villiers et al. 2004).

Based on the viral DNA sequence, more than 230 HPV types are known (Haws et al. 2004); 118 genotypes are well-characterised according to biological niche, oncogenic potential and phylogenetic position (de Villiers et al. 2004). Approximately $40 \mathrm{HPV}$ types infect the anogenital region and 15 of them - 16, 18, 31, 33, 35, $39,45,51,52,56,58,59,68,73$ and 82 - are considered oncogenic or as high risk because they are associated with high grade squamous intraepithelial lesions or cancer. Types 26, 53 and 66 are likely to be carcinogenic, whereas types $6,11,40,42,43,44,54,61,70,72,81$ and candHPV89/Cp6108 are considered to be low risk (Munoz et al. 2003).

HPVs have been associated with many proliferative lesions, with condyloma acuminatum being the most common, as well as with different types of cancer, including cervical, vaginal, vulvar, penile, anal, oropharyngeal, buccal cavity and larynx (Bosch et al. 2002, Montaldo et al. 2007). Among them, uterine cervix carcinoma is particularly important due to its high incidence and its high

Financial support: NUPAD, Faculdade de Medicina - UFMG + Corresponding author: nocarvalho@gmail.com

Received 19 July 2009

Accepted 21 December 2009 mortality rate. In most cases, tumours evolve slowly and can be prevented by identifying precursor lesions in the cervical epithelium as early as possible, allowing for effective treatment before local invasion and spread of the disease (Bezerra et al. 2005).

A strong association between HPV and cervical cancer stimulated the development of several diagnostic tests, particularly those based on molecular biology. There are currently two main approaches for molecularly detecting HPV: PCR with generic primers to amplify part of the L1 gene of the viral capsid, which is highly conserved among anogenital HPVs and the hybrid capture test (HC2), which detects the main types of HPV by forming DNA-RNA hybrids (Iftner \& Villa 2003, Giovannelli et al. 2004, Carestiato et al. 2006). As it is more sensitive, PCR has been largely used worldwide (Gravitti et al. 2000, Hubbard 2003, Kosel et al. 2003).

The diversity of virus types and the incidence of multiple infections have made it necessary to develop reliable methods to identify the different genotypes, for epidemiological studies as well as for the patient follow up (Sotlar et al. 2004). As no test has officially been approved for HPV genotyping (Meijer et al. 2003), several methods have been used to identify different virus types, including PCR with generic primers (Gravitti et al. 2000), RFLP (Astori et al. 1997), hybridisation with specific probes (Mendez et al. 2005), reverse hybridisation line probe assay - HPV-LiPA (Kleter et al. 1999), reverse line-blot hybridisation (Mendez et al. 2005), nucleotide sequencing (Verteramo et al. 2006, Fontaine et al. 2007, Lee et al. 2007, Montaldo et al. 2007) and DNA Chip (Choi et al. 2005). PCR with specific primers (TS-PCR) for each virus type is another approach and is based on polymorphisms, mainly E6 and E7. This is a highly sensitive method that is easy to interpret and 
can characterise virus types in cases of multiple infection (Hubbard 2003, Sotlar et al. 2004, Carestianto et al. 2006, Fontaine et al. 2007, Lin et al. 2008). Selecting virus types to be tested should be based on epidemiological and prevalence studies, as there is a wide variation in the genotype distribution in different regions around the world.

Over the last few years, virus genotyping has become an important way to approach cervical cancer. Several groups have searched for an effective genotyping test for $\mathrm{HPV}$, due to its great contribution in the diagnosis of infections and to a better understanding of the relationship of HPV with carcinogenesis, in addition to contributing to the development of type-specific vaccines. This study compared two methods of HPV genotyping (TS-PCR and sequencing) to find an effective strategy for virus genotyping in clinical samples.

\section{SUBJECTS, MATERIALS AND METHODS}

Study population - The present study was part of a multicentric research project entitled Multicentric Programme for Controlling and Preventing High Degree Cervical Lesions and Cervical Uterine Cancer in HIVpositive Women. Samples came from HIV-infected women attended at the Centro de Treinamento e Referência em Doenças Infecciosas e Parasitária Orestes Diniz, in Belo Horizonte or at public gynaecology outpatient clinics in other cities (Betim, Barbacena, Divinópolis and Conselheiro Lafaiete), all of which were in state of Minas Gerais. From February 2006-February 2008, 463 samples were analysed; 260 were included in this study as they were HPV-positive and 203 were excluded (187 samples were HPV negative and 16 samples were globin negative). The research study was approved by the Research Ethical Committee of the Universidade Federal de Minas Gerais; all participants gave written consent.

Sample collection and processing - Cervical cells were obtained with an Ayre's spatula and placed in a sterile tube containing $2 \mathrm{~mL}$ of physiological saline solution $(\mathrm{NaCl}, 0.09 \%)$; samples were sent to the laboratory within 24 h. Cytological results of the Papanicolaou test were not included.

DNA was extracted using Chelex 100 chelating resin (BioRad), according to the manufacturer's protocol (Walsh et al. 1991). To control for DNA quality, the globin gene was amplified (Duggan et al. 1994) in all samples. PCR was performed in a final reaction volume of $50 \mu \mathrm{L}$, containing $10 \mu \mathrm{L}$ of DNA, $5 \mu \mathrm{L}$ buffer $10 \times[100$ $\mathrm{mM}$ Tris- $\mathrm{HCl}(\mathrm{pH} 8,8) 500 \mathrm{mM} \mathrm{KCl}], 3 \mu \mathrm{L} \mathrm{MgCl}_{2}, 1 \mu \mathrm{L}$ dNTPs $[200 \mu \mathrm{M}], 2,5 \mu \mathrm{L}$ of each primer at $10 \mathrm{pmol} / \mu \mathrm{L}$ and 2.5 U of Taq DNA polymerase. The PCR conditions were as follows: preheating for $1 \mathrm{~min}$ at $94^{\circ} \mathrm{C}$ was followed by 30 cycles of $30 \mathrm{sec}$ at $90^{\circ} \mathrm{C}, 2 \mathrm{~min}$ at $54^{\circ} \mathrm{C}$ and $1 \mathrm{~min}$ at $72^{\circ} \mathrm{C}$ and a final extension of $10 \mathrm{~min}$ at $72^{\circ} \mathrm{C}$. HPV detection by PCR was carried out in a nested-PCR system, using the primers MY09/11 (Manos et al. 1989) and GP5+/6+ (de Roda Husman et al. 1995). For the first reaction, the same conditions were used as those for globin gene. Nested-PCR was performed in a final volume of $50 \mu \mathrm{L}$, containing $1 \mu \mathrm{L}$ of the first reaction, $5 \mu \mathrm{L}$ buffer $10 \times$ [100 mM Tris- $\mathrm{HCl}(\mathrm{pH} \mathrm{8,8)} 500 \mathrm{mM} \mathrm{KCl}], 3$ $\mu \mathrm{L} \mathrm{MgCl}, 1 \mu \mathrm{L}$ dNTPs $(200 \mu \mathrm{M}), 2,5 \mu \mathrm{l}$ of each primer at $10 \mathrm{pmol} / \mu \mathrm{L}$ and $2,5 \mathrm{U}$ of Taq DNA polymerase. The PCR conditions were as follows: preheating for $4 \mathrm{~min}$ at $94^{\circ} \mathrm{C}$ was followed by 40 cycles of $30 \mathrm{sec}$ at $94^{\circ} \mathrm{C}, 1 \mathrm{~min}$ at $45^{\circ} \mathrm{C}$ and $1 \mathrm{~min}$ and $30 \mathrm{sec}$ at $72^{\circ} \mathrm{C}$ and the final extension of $10 \mathrm{~min}$ at $72^{\circ} \mathrm{C}$.

TS PCR - DNA was amplified with specific primers for the following HPV types: 6, 11, 16, 18, 31, 33 and 35 (Arndt et al. 1994, Duggan et al. 1994) in independent reactions. PCR was performed in a final reaction volume of $50 \mu \mathrm{L}$, containing $5 \mu \mathrm{L}$ of DNA, $5 \mu \mathrm{L}$ buffer $10 \times[100$ $\mathrm{mM}$ Tris- $\mathrm{HCl}$ ( $\mathrm{pH} 8.8), 500 \mathrm{mM} \mathrm{KCl}$, $3 \mu \mathrm{L} \mathrm{MgCl}_{2}, 1$ $\mu \mathrm{L}$ dNTPs $(200 \mu \mathrm{M}), 2.5 \mu \mathrm{L}$ of each primer at $10 \mathrm{pmol} /$ $\mu \mathrm{L}$ and $2.5 \mathrm{U}$ of Taq DNA polymerase. Amplification conditions were the same as those for globin gene, except for annealing temperatures, which were as follows: for HPV types 16,31 and $35: 2 \mathrm{~min}$ at $54^{\circ} \mathrm{C}$; for $\mathrm{HPV}$ type $6: 2 \mathrm{~min}$ at $56^{\circ} \mathrm{C}$; for $\mathrm{HPV}$ type $11: 2 \mathrm{~min}$ at $61^{\circ} \mathrm{C}$;

TABLE I

Primer sequences

\begin{tabular}{|c|c|c|c|}
\hline Types & Sequences & Region of viral genome & Product size \\
\hline $6 \mathrm{~A}$ & 5'-TAGGGGACGGTCCTCTATTC-3 & & \\
\hline $6 \mathrm{~B}$ & 5'-GCAACAGCCTCTGAGTCACA-3 & LCR & $258-361 \mathrm{pb}$ \\
\hline $11 \mathrm{~A}$ & 5'-GAATACATGCGCCATGTGGA-3' & & \\
\hline 11B & 5'-AGCAGACGTCCGTCCTCGAT-3' & L1 & $356 \mathrm{pb}$ \\
\hline $16 \mathrm{~A}$ & 5’-TCAAAGCCACTGTGTCCTG-3' & & \\
\hline $16 \mathrm{~B}$ & 5'-CGTGTTCTTGATGATCTGCAA-3' & E6 & $271 \mathrm{pb}$ \\
\hline $18 \mathrm{~A}$ & 5'-TGGTGTATAGAGACAGTATACCCCA-3 & & \\
\hline 18B & 5'-GCCTCTATAGTGCCCAGGTATGT-3' & E6 & $247 \mathrm{pb}$ \\
\hline $31 \mathrm{~A}$ & 5'-TGAACCGAAAACGGTTGGTA-3' & & \\
\hline 31B & 5'-CTCATCTGAGCTGTCGGGTA-3' & E6/E7 & $613 \mathrm{pb}$ \\
\hline $33 \mathrm{~A}$ & 5'-AGTAGGGTGTAACCGAAAGC-3' & & \\
\hline 33B & 5'-CTTGAGGACACAAAGGTCTT-3' & E6 & $411 \mathrm{pb}$ \\
\hline $35 \mathrm{~A}$ & 5'-GAATTACAGCGGAGTGAGGT-3' & & \\
\hline $35 \mathrm{~B}$ & 5'-CACCGTCCACCGATGTTATG-3' & E6 & $290 \mathrm{pb}$ \\
\hline
\end{tabular}


for HPV type $18: 2 \mathrm{~min}$ at $58^{\circ} \mathrm{C}$; for HPV type $33: 2 \mathrm{~min}$ at $50^{\circ} \mathrm{C}$. All PCR products were submitted to agarose gel electrophoresis in a $2 \%$ gel, treated with ethidium bromide and analysed under UV light. Primer sequences and fragment sizes are shown in Table I.

Direct sequencing - Approximately $30 \mu \mathrm{L}$ of the nested-PCR product of each sample was purified and sequenced using the BigDye Terminator kit version 3.1 (Applied Biosystems) and Gp6+ primer (4 pmol/ $\mu \mathrm{L})$, according to the manufacturer's instructions. Sequences were read on a 3100-Avant Genetic Analyser ABI Prism sequencer (Applied Biosystems). Each sequence obtained was edited by selecting a segment of 30 nucleotides. The size and location of the L1-amplified region segment were chosen based on the degree of polymorphisms and according to published HPV sequencing methods (FeoliFonseca et al. 1998, Lee et al. 2007). Sequences of 30 nucleotides were aligned using the Bioedit programme (version 7.0) (Hall 1999) with HPV reference sequences obtained from the ICTVdB database (http://www.ictvdb. rothamsted.ac.uk/). A complementary analysis of sequences obtained from Blast was performed (http://www.ncbi.nlm. nih.gov/blast).

Data analysis - Data were tabulated using Microsoft Office Excel 2007. The Mcnemar statistical test was used to compare the effectiveness of both methods at identifying the virus type. Differences were considered significant at $\mathrm{p}<0.05$.

\section{RESULTS}

Using the two strategies (TS-PCR and sequencing), the HPV genotype was identified in $227(87 \%)$ of the 260 samples. In 33 cases (13\%), it was not possible to identify the virus genotype due to the presence of non-screened

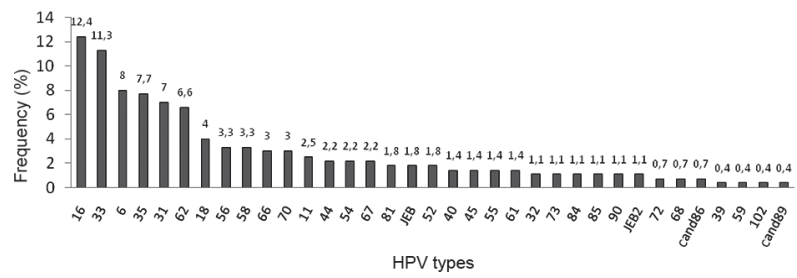

Fig. 1: frequency of the human papillomavirus virus (HPV) types identified.

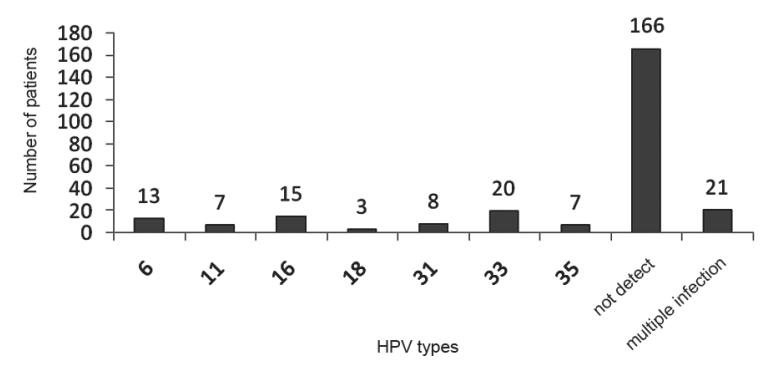

Fig. 2: genotyping by type-specific PCR. HPV: human papillomavirus. types in the panel investigated by the TS-PCR and/or to the occurrence of multiple-type infection, which cannot be typed by sequencing. In Fig. 1, the frequency of the 35 types identified in the study are shown, with HPV 16 (12.4\%), HPV 33 (11.3\%) and HPV 6 (8\%) being the most frequent types identified. Table II shows the types identified for each case.

Using TS-PCR for the seven types investigated, it was possible to genotype the virus in 94/260 (36\%) cases. More than one virus type was identified in 21 of the cases. However, the virus type was not identified by TS-PCR in 166/260 (64\%) cases, as shown in Fig. 2.

TABLE II

Human papillomavirus (HPV) genotypes in 260 cases

\begin{tabular}{|c|c|c|c|}
\hline \multicolumn{2}{|c|}{ Simple infection } & \multicolumn{2}{|c|}{ Multiple infection } \\
\hline & Cases & & Cases \\
\hline HPV types ${ }^{a}$ & $\mathrm{n}$ & HPV types & $\mathrm{n}$ \\
\hline 6 & 20 & 33 and other (s) & 8 \\
\hline 16 & 17 & 33 and 67 & 4 \\
\hline 62 & 15 & 33 and 58 & 4 \\
\hline 56 & 8 & 16, 31 and 33 & 3 \\
\hline 66 & 8 & 16 and 35 & 3 \\
\hline 70 & 8 & 31 and 35 & 3 \\
\hline 18 & 6 & 16 and other (s) & 3 \\
\hline 11 & 6 & 31 and other (s) & 3 \\
\hline 35 & 6 & 16,33 and 35 & 2 \\
\hline 44 & 6 & 16 and 18 & 2 \\
\hline 31 & 6 & 35 and other (s) & 2 \\
\hline 54 & 5 & $16,31,33$ and 35 & 1 \\
\hline 81 & 5 & $6, \mathbf{1 6}, \mathbf{3 3}$ and 35 & 1 \\
\hline JEB & 5 & 6, 18 and $\mathbf{3 3}$ & 1 \\
\hline 40 & 4 & 18,31 and 33 & 1 \\
\hline 45 & 4 & 33,56 and 58 & 1 \\
\hline 52 & 4 & 33, 62 and other (s) & 1 \\
\hline 55 & 4 & 16 and 31 & 1 \\
\hline 58 & 4 & 31 and 35 & 1 \\
\hline 61 & 4 & 18 and 33 & 1 \\
\hline 32 & 3 & 16 and 33 & 1 \\
\hline 73 & 3 & 33 and 62 & 1 \\
\hline 84 & 3 & 52 and 67 & 1 \\
\hline 85 & 3 & 35 and JEB2 & 1 \\
\hline 90 & 3 & 35 and 54 & 1 \\
\hline 72 & 2 & 62 and other (s) & 1 \\
\hline 68 & 2 & 11 and other (s) & 1 \\
\hline cand86 & 2 & type not identify & 33 \\
\hline JEB2 & 2 & Subtotal & 86 \\
\hline 33 & 1 & - & - \\
\hline 39 & 1 & - & - \\
\hline 59 & 1 & - & - \\
\hline 67 & 1 & - & - \\
\hline 102 & 1 & - & - \\
\hline cand89 & 1 & - & - \\
\hline Subtotal & 174 & - & - \\
\hline Total & 260 & - & - \\
\hline
\end{tabular}

$a$ : boldface indicates high-risk type. Classification according de Villiers et al. (2004). 
Direct sequencing of the amplified product identified the virus type in 196/260 (75\%) cases. The types were distinct from those included in the panel surveyed by TS-PCR in 123 of the cases. The presence of more than one virus type, characterised by overlapping sequences, was seen in 68/260 (26\%) cases, making it impossible to identify the types present in the great majority of cases; the types were identified in only four of these cases. Therefore, sequencing failed to identify the virus genotype in 64/260 (25\%) cases. In addition to the seven types investigated by TS-PCR (types $6,11,16,18,31$, 33 and 35), 28 other HPV types were identified by sequencing $(32,39,40,44,45,52,54,55,56,58,59,62$, $61,66,67,68,70,72,73,81,84,85,90,102$, cand 86 , cand 89 and two types that still have not been classified taxonomically, the isolated JEB and type JEB2). These results are shown in Fig. 3.

Regarding multiple infections ( $\mathrm{n}=86)$, TS-PCR identified more than one virus type in 21/86 (24\%) cases, but it failed to identify multiple types in seven of the cases, recognising only one of the types present in the sample. In contrast, sequencing identified multiple infections in $68 / 86$ (79\%) samples and it was possible to identify multiple types or at least one virus type in only $4 / 86(4.6 \%)$. Considering the results of both techniques together, multiple types or at least one type were identified in 53/86 $(62 \%)$ cases of multiple infection. The typing result was different between the two methods employed in 12 cases. In the 19 cases of discordance between TS-PCR and sequencing ( 7 in which sequencing failed to identify multiple types and 12 in which typing was different in both methods), we considered that more than one virus type was present in the sample because sequencing may fail to identify multiple types.

When the effectiveness of both methods to identify HPV types present in samples was compared, sequencing identified the genotype in more cases than TS-PCR for the seven types studied at the significance level. The estimated odds ratio showed that sequencing had a 4.2fold greater chance of identifying the virus type present in a positive sample than TS-PCR for the seven types investigated (Table III).

\section{DISCUSSION}

Molecular tests may accurately identify different types of HPV (of low and high cancer risk) in cells from cytological screening of cervical lesions and, due to their high sensitivities, have been the focus of attention of many studies (Gravitti et al. 2000, Hubbard 2003, Kosel et al. 2003). It is not always possible to identify the infecting virus type using PCR as a diagnostic method. The use of MY09/11 and GP5+/6+ primers in the nestedPCR system was proposed as a way to reduce this limitation, in addition to enhancing detection sensitivity, with a positivity rate $38.8 \%$ higher than that when MY09/11 was used alone; in this system, HPV can be detected in samples containing a low number of viral DNA copies (Pannier-Stockman et al. 2008). In the present study, the MY09/11 and GP5+/6+ strategy was employed and HPV90 and HPVcand86 were amplified. According to Terai and Burk (2002), these HPV types do not amplify

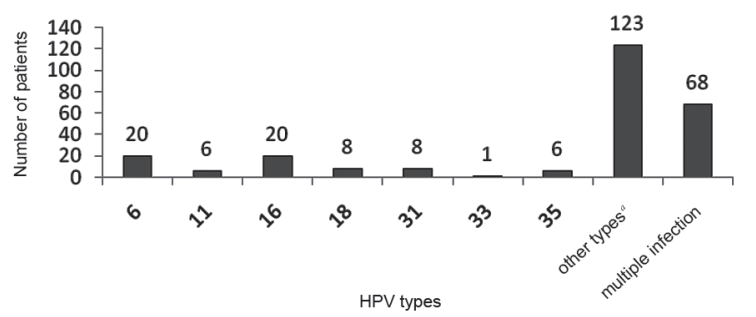

Fig. 3: genotyping by sequencing. $a$ : human papillomavirus (HPV) types identified only by sequencing: $32,39,40,44,45,52,54,55$, $56,58,59,62,61,66,67,68,70,72,73,81,84,85,90,102$, cand 86 , cand89, JEB and JEB2.

TABLE III

Analysis type-specific PCR (TS-PCR) vs. sequencing

\begin{tabular}{lccc}
\hline & \multicolumn{3}{c}{ TS-PCR } \\
\cline { 2 - 4 } Sequencing & Identified type & Not identified type & Total \\
\hline Identified type & 63 & 133 & 196 \\
Not identified type & 31 & 33 & 64 \\
\hline Total & 94 & 166 & 260
\end{tabular}

confidence interval de $95 \%$ for odds ratio (OR): $2.90 \leq \mathrm{OR}_{\text {estimated }}$ $\geq 6.34$. OR: $133 / 31=4.29$.

using MY09/11 alone. Speich et al. (2004) compared the genotyping results obtained when the MY09/11 and GP5+/6+ primers were used alone. They verified that MY failed to amplify types $30,42,43,51,59,67,74,92$ and 91 and that GP was unable to amplify types 61 and 62. In this study, types 59, 67, 90, 61 and 62 were amplified and type 62 was the sixth most prevalent.

A total of 35 virus types were identified in this study, two of which have not yet been taxonomically classified: isolated JEB and type JEB2. Furthermore, 16 high risk genotypes were identified, two of which (HPV67 and HPV70) were not included in the set investigated using the $\mathrm{HC} 2$ test. This data indicates that a large variety of virus is present in clinical samples, demonstrating the importance of PCR and sequencing as helpful tools for providing relevant information on the HPV infection. It was not possible to correlate the $\mathrm{SiL} / \mathrm{CIN}$ grade of the lesion with the HPV DNA found in this study because its main goal was to compare the effectiveness of TS PCR (TS-PCR) and sequencing, with focuses on their clinical application.

TS-PCR for the seven HPV types examined $(6,11$, $16,18,31,33$ and 35) identified multiple types or at least one type in only $94 / 260(36 \%)$ of cases. These types were chosen because types 16, 18, 31, 33 and 35 are among the eight most prevalent types in cervical cancer worldwide (Clifford et al. 2006) and therefore of great importance and types 6 and 11 were chose because they are of low risk, as they are found in up to $95 \%$ of cases of condyloma acuminatum. The low effectiveness of this method for genotyping may be attributed to the small number of types investigated in addition to the great variety of 
types present in these patients. Sequencing identified virus types in a larger number of cases $(196 / 260,75 \%)$ and recognised 28 types absent from the panel investigated by TS-PCR. Nevertheless, it was disadvantaged at identifying genotypes in samples with multiple infections, in which viral sequences overlap and it is not possible to distinguish the various types, a finding also reported by others (Vernon et al. 2000, Serrano et al. 2003, Choi et al. 2005). In this study, sequencing was able to identify types in only four cases of multiple infection, which were those having only two virus types in the sample. By sequencing, $25 \%$ of cases were not genotyped.

The greatest advantage of TS-PCR was its ability to identify multiple virus types or at least one virus type in cases of multiple infections $(53 / 86,62 \%$ of the samples in this series). However, this procedure requires several reactions for each sample and is more laborious, an opinion also shared by Lin et al. (2008). According to these authors, several reactions are required to investigate the great number of virus types, which makes this strategy non-viable for large-scale studies.

The results of the two methodologies were discrepant in 19 cases. In 10 of these cases, TS-PCR identified type 33 and sequencing identified types 58 (4 cases), 67 (4 cases), 62 (1 case) and 56/58 (1 case); in two cases, TSPCR identified type 35 and sequencing identified types 54 (1 case) and JEB2 (1 case); in seven other cases, sequencing identified only one virus type in the sample, whereas TS-PCR identified more than one type. Such discordances may be attributed to favouring the amplification of these types in the PCR reaction, a phenomenon that can occur when there is more than one virus type; in these cases, the type or types amplified are those existing in larger amounts in the sample. Kado et al. (2001) compared typing using sequencing $(\mathrm{n}=$ 107) with five different primers (GP17/18, MY09/11, L1C1/L1C2+L1C2M, pU1M-L/pU-2R and pU1M-L/ pU-2R-N) and they identified a different genotype in five cases, indicating a multiple infection. According to the authors, different types of HPV were preferably amplified depending on the primer used. Although this possibility is plausible, more studies are necessary to explain such differences.

As already reported in other studies (Serrano et al. 2003, Fontaine et al. 2007) and in spite of its limitations, sequencing has been considered the gold standard for HPV genotyping, due to the possibility of identifying virtually all virus types without mistaken classifications through cross-reactions among similar types, which can occur using tests based on hybridisation. This study demonstrated that sequencing was more effective in recognising types of HPV, having identified 4.2 more cases than TS-PCR for the seven types studied and that both methods have advantages and disadvantages. Therefore, the best approach is the combination of both methods.

Based on our results, we suggest that both methods be employed as a genotyping strategy for HPV in clinical practice because they have been shown to be complementary methods. Due to its great genotyping effectiveness, sequencing should be used in research studies or in those cases of recurrent/persistent/untreatable infections not typed by TS-PCR. When choosing types to be investigated by TS-PCR, a panel should include the most prevalent high risk types and those with greater clinical relevance. Some studies (Chow et al. 2000, Fontaine et al. 2007, Capra et al. 2008, Pannier-Stockman et al. 2008) have proposed to use TS-PCR after sequencing to identify HPV DNA, with consideration of the great variety of virus types, which are different in biological properties and carcinogenic risk.

\section{ACKNOWLEDGMENTS}

To Prof. Arminda Siqueira Campos and Jacqueline Tibúrcio, for their help with statistics.

\section{REFERENCES}

Ardnt A, Nottelmann K, Brock J, Neumann OG 1994. Das invert papillom und seine assoziation mit dem humanen papillomavirus (HPV). HNO 42: 670-676.

Astori G, Arzese A, Pipan C, de Villiers E-M, Botta GA 1997. Characterization of a putative new HPV genomic sequence from a cervical lesion using L1 consensus primers and restriction fragment length polymorphism. Virus Res 50: 57-63.

Bezerra SJS, Gonçalves PC, Franco ES, Pinheiro AKB 2005. Perfil de mulheres portadoras de lesões cervicais por HPV quanto aos fatores de risco para câncer de colo de útero. J Bras Doenças Sex Transm 17: 143-148.

Bosch FX, Lorincz A, Munoz N, Meijer CJLM, Shah KV 2002. The causal relation between human papillomavirus and cervical cancer. J Clin Pathol 55: 244-265.

Capra G, Giovannelli L, Bellavia C, Migliore MC, Caleca MP, Perino A, Ammatuna P 2008. HPV genotype prevalence in cytologically abnormal cervical samples from women living in South Italy. $\mathrm{Vi}$ rus Res 133: 195-200.

Carestiato FN, Silva KC, Balthazar DS, Silva L, Marinho M, Oliveira LHS, Cavalvanti SMB 2006. Analysis of molecular biology techniques for the diagnosis of human papillomavirus infection and cervical cancer prevention. Rev Soc Bras Med Trop 39: 428-432.

Choi Y-D, Jung W-W, Nam J-H, Choi H-S, Park C-S 2005. Detection of HPV genotypes in cervical lesions by the HPV DNA chip and sequencing. Ginecol Oncol 98: 369-375.

Chow VTK, Loh E, Yeo WM, Tan SY, Chan R 2000. Identification of multiple genital HPV types and sequence variants by consensus and nested type-specific PCR coupled with cycle sequencing. Pathology 32: 204-208.

Clifford G, Franceschi S, Diaz M, Munoz N, Villa LL 2006. Chapter 3: HPV type-distribution in women with and without cervical neoplastic diseases. Vaccine 24S3: 26-34.

de Roda Husman A-M, Walboomers JMM, van den Brule AJC, Meijer CJLM, Snijders PJF 1995. The use of general primers GP5 and GP6 elongated at their 3' ends with adjacent highly conserved sequences improves human papillomavirus detection by PCR. J Gen Virol 76: 1057-1062.

de Villiers E-M, Fauquet C, Broker TR, Bernard H-U, zur Hausen H 2004. Classification of papillomaviruses. Virology 324: 17-27.

Duggan MA, Inoue M, Mcgregor SE, Stuart GCE, Morris S, Poon VG, Schepansky A, Honore L 1994. A paired comparison of dot blot hybridization and PCR amplification for HPV testing of cervical scrapes interpreted as CIN 1. Eur J Gynaec Oncol 15: 178-187.

Feoli-Fonseca JC, Oligny LL, Filion M, Brochu P, Simard P, Russo, PA, Yotov WV 1998. A two-tier polymerase chain reaction direct sequencing method for detection and typing human papillomavirus in pathological specimens. Diagn Mol Pathol 7: 317-323. 
Fontaine V, Mascaux C, Weyn C, Bernis A, Celio N, Lefevre P, Kaufman L, Garbar C 2007. Evaluation of combined general primermediated PCR sequencing and type-specific PCR strategies for determination of human papillomavirus genotypes in cervical cell specimens. J Clin Microbiol 45: 928-934.

Giovannelli L, Lama A, Capra G, Giordano V, Arico P, Ammatuna $P$ 2004. Detection of human papillomavirus DNA in cervical samples: analysis of the new PGMY-PCR compared to Hybrid Capture II and MY-PCR assay and two-step nested PCR assay. J Clin Microbiol 42: 3861-3864.

Gravitti PE, Peyton CL, Alessi TQ, Wheeler CM, Coutlee F, Hildesheim A, Schiffiman MH, Scott DR, Apple RJ 2000. Improved amplification of genital humam papillomaviruses. J Clin Microbiol 38: 357-361.

Hall TA 1999. Bioedit: a user-friendly biological sequence alignment editor and analysis program for Windows 95/98NT. Nucleic Acids Symp Ser 41: 95-98.

Haws ALF, He Q, Rady PL, Zhang L, Grady J, Hughes TK, Stisser K, Konig R, Tyring SK 2004. Nested PCR with the PGMY09/11 and GP5+/6+ primer sets improves detection of HPV DNA in cervical samples. J Virol Methods 122: 87-93.

Hubbard RA 2003. Human papillomavirus testing methods. Arch Pathol Lab Med 127: 940-945.

Iftner T, Villa LL 2003. Chapter 12: human papillomavirus technologies. J Natl Cancer Inst Monographs 31: 80-88.

Kado S, Kawamata Y, Shino Y, Kasai T, Kubota K, Iwasaki H, Fukazawa I, Takano H, Nuoyama T, Mitsuhashi A, Sekiya S, Shirasawa $\mathrm{H}$ 2001. Detection of human papillomavirus in cervical neoplasias using multiple sets of generic polymerase chain reaction primers. Ginecol Oncol 81: 47-52.

Kleter B, van Doorn L-J, Schrauwen L, Molijn A, Sastrowijoto S, ter Schegguet J, Lindeman J, ter Harmsel B, Burger M, Quint W 1999. Development and clinical evaluation of a highly sensitive PCR-reverse hybridization line probe assay for detection and identification of anogenital human papillomavirus. J Clin Microbiol 37: 2508-2517.

Kosel S, Burggraf S, Mommsen J, Engelhardt W, Olgemoller B 2003. Type-specific detection of human papillomaviruses in a routine laboratory setting - improved sensitivity and specificity of PCR and sequence analysis compared to direct hybridization. Clin Chem Lab Med 41: 787-791.

Lee SH, Vigliotti VS, Vigliotti JS, Pappu S 2007. Routine human papillomavirus genotyping by DNA sequencing in community hospital laboratories. Infect Agents Cancer 2: 1-11.

Lin C-Y, Chao A, Yang Y-C, Chou H-H, Ho C-M, Lin R-W, Chang T-C, Chiou J-Y, Chao F-Y, Wang K-L, Chien T-Y, Hsueh S, Huang C-C, Chen C-J, Lai C-H 2008. Human papillomavirus typing with a polymerase chain reaction-based genotyping array compared with type-specific PCR. J Clin Virol 42: 361-367.

Manos MM, Ting Y, Wright DK, Lewis AJ, Broker TR, Wolinsky SM 1989. Use of polymerase chain reaction amplification for the detection of genital human papillomaviruses. Cancer Cells 7: 209-214.
Meijer CJ, Snijders PJ, Castle PE 2003. Clinical utility of HPV genotyping. Gynecol Oncol 103: 12-17.

Mendez F, Munoz N, Posso H, Molano M, Moreno V, van den Brule AJC, Ronderos M, Meijer C, Munoz A 2005. Cervical coinfection with human papillomavirus (HPV) types and possible implications for the prevention of cervical cancer by HPV vaccines. J Infect Dis 192: 1158-1165.

Montaldo C, Mastinu A, Quartuccio M, Piras V, Denotti G, Pisano E, Orrú G 2007. Detection and genotyping of human papillomavirus DNA in samples from healthy Sardinian patients: a preliminary study. J Oral Pathol Med 36: 482-487.

Munoz N, Bosch FX, Sanjosé S, Herrero R, Castellsagué X, Shah KV, Snijders PJF, Meijer CJLM 2003. Epidemiologic classification of human papillomavirus types associated with cervical cancer. N Eng J Med 348: 518-527.

Pannier-Stockman C, Segard C, Bennamar S, Gondry J, Boulanger J-C, Sevestre H, Castelain S, Duverlier G 2008. Prevalence of HPV genotypes determined by PCR and DNA sequencing in cervical specimens from French women with or without abnormalities. J Clin Virol 42: 353-360.

Sanjose S, Diaz M, Castellsague X, Clifford G, Bruni L, Munoz N, Bosch FX 2007. Worldwide prevalence and genotypes distribution of cervical human papillomavirus DNA in women with normal cytology: a meta-analysis. Lancet Infect Dis 7: 453-459.

Serrano ML, Correa M, Medina O, Melgarejo D, Bravo MM 2003. Tipificación de vírus del papiloma humano mediante secuencia directa em mujeres com citologia normal. Rev Colomb Cancer 7: 18-24.

Sotlar K, Diemer D, Dethleffs A, Hack Y, Stubner A, Vollmer N, Menton S, Menton M, Dietz K, Wallwiener D, Kandolf R, Bultmann B 2004. Detection and typing of human papillomavirus by E6 nested multiplex PCR. J Clin Microbiol 42: 3176-3184.

Speich N, Schimitt C, Bollmann R, Bollmann M 2004. Human papillomavirus (HPV) study of 2,916 cytological samples by PCR and DNA sequencing: genotype spectrum of patients from the West German area. J Med Microbiol 53: 125-128.

Terai M, Burk RD 2002. Identification and characterization of 3 novel genital human papillomaviruses by overlapping polymerase chain reaction: candHPV89, candHPV 90 and candHPV91. J Infect Dis 185: 1794-1797.

Vernon SD, Unger ER, Willians D 2000. Comparison of human papillomavirus detection and typing by cycle sequencing, line blotting and hybrid capture. J Clin Microbiol 38: 651-655.

Verteramo R, Pierangeli A, Calzolari E, Patella A, Recine N, Mancini E, Marcone V, Masciangelo R, Bucci M, Antonelli G, Degener AM 2006. Direct sequencing of HPV DNA detected in gynaecologic outpatients in Rome, Italy. Microbes Infect 8: 2517-2521.

Walsh PS, Metzger DA, Higuchi R 1991. Clelex 100 as a medium for simple extraction of DNA for PCR-based typing from forensic material. Biotechniques 10: 606-513. 